\title{
ORGANISATION OF TEXTILE PRODUCTION IN THE SETTLEMENT OF THE LUSATIAN CULTURE AT RUDA, GRUDZIĄDZ COMMUNE
}

\begin{abstract}
The subject of this article is the organisation of textile production in the settlement of the Lusatian Culture in the village of Ruda, Grudziądz Commune, Kujawsko-Pomorskie Voivodeship. The discovery of 63 spindle whorls and their fragments, as well as two objects, interpreted as loom weights, has triggered a discussion of the textile production. The discovered archaeological Feature 1351F has been interpreted as a remnant of a warp-weighted loom, similar to that from Wallwitz in Saxony. From the point of view of the organisation of textile manufacture in the settlement in question, the most important is the fact that most archaeological artefacts were discovered within identified households. Together with accompanying storage pits, they formed close single enclosures. The distribution of spindle whorls within enclosures seems to be significant.
\end{abstract}

Keywords: textile production, spindle whorls, loom weights, Lusatian Culture

\section{Introduction}

The subject of this article is the organisation of textile production in the settlement of the Lusatian Culture in the village of Ruda, Grudziądz Commune, Kujawsko-Pomorskie Voivodeship. The site of Ruda 3-6 was examined in the years 2000-2002, during excavations preceding the construction of the A1 motorway. The examinations were conducted by the Institute of Archaeology and Ethnology of the Nicolaus Copernicus University in Torun. The substantive supervision over the works was carried out by coordinators of the team of A-1 Motorway Survey in the Institute of Archaeology and Ethnology of the Nicolaus Copernicus University in Torun. ${ }^{1}$

Based on surface works, tests drills and sonographic surveys, the size of the settlement was assessed at 30 hectares. Rescue excavations covered the area of about 10 hectares which corresponded to the area of the motorway construction project. $^{2}$ Several expert analyses were performed to reconstruct the natural and cultural conditions of the then-existing communities, including soil and palaeogeomorphological, archaeozoological, archaeobotanical and malacological

* Institute of Archaeology, Nicolaus Copernicus University in Torun; (D) https://orcid.org/0000-0002-4169-0154; m.przymorska@gmail.com

${ }^{1}$ Chudziak 2006b, 16.

${ }^{2}$ Chudziak 2006b, 16. expertises, imprints of plants on ceramics and pugging, morphological analyses of flint and stone artefacts. ${ }^{3}$

During rescue excavations, more than 100,000 fragments of ceramic vessels of the Lusatian Culture were uncovered. Furthermore, objects of historical value related to bronze production, such as fragments of casting crucibles and moulds, bronze ornaments, sickles and axes, were discovered at the site of Ruda. In addition, numerous flint tools, bone tools, quern-stones and grinders, as well as clay rattles were unearthed. ${ }^{4}$ However, the discovery of 63 spindle whorls and their fragments, two objects interpreted as loom weights, as well as Feature $1351 \mathrm{~F}$ interpreted as remains of a warp-weighted loom, was particularly important for the research on textile production. The textile tools have been preserved mostly within the archaeological features (pits) within individual enclosures.

\section{Physiography and chronology of the site}

The Ruda 3-6 site is located within the Lower Vistula Valley, in the eastern part of the Grudziądzka Basin, which borders with the Kwidzynska Valley in the north, adjoins the Tuchola Forest plateau in the west, the Chełmińskie Lake District in the east and the Fordońska Valley in the south. ${ }^{5}$

\footnotetext{
${ }^{3}$ Chudziak 2006a, 8.

${ }^{4}$ Rembisz 2006, 348-355.

${ }^{5}$ Kondracki 2000, 89.
} 


\begin{tabular}{|c|c|c|c|c|}
\hline $\mathbf{B C}$ & O. Montelius & P. Reinecke & J. Kostrzewski & Ruda site 3-6 \\
\hline 300 & \multirow{3}{*}{$\begin{array}{l}\text { Pre-Roman Iron } \\
\text { Age }\end{array}$} & \multirow[b]{2}{*}{ La Tène $A$ and $B$} & \multirow[b]{2}{*}{ Early La Tène } & \\
\hline 400 & & & & \multirow{2}{*}{ Phase III } \\
\hline 500 & & $\mathrm{HD}$ & DP & \\
\hline 600 & VI & $\mathrm{HC}$ & $\mathrm{HC}$ & Phase II \\
\hline 700 & & \multirow{3}{*}{$\mathrm{HB}$} & & \multirow{3}{*}{ Phase I b } \\
\hline 800 & $\mathrm{v}$ & & $\mathrm{V}$ & \\
\hline 900 & \multirow{2}{*}{ IV } & & \multirow{2}{*}{ IV } & \\
\hline 1000 & & \multirow{2}{*}{$\mathrm{HA}$} & & \multirow{2}{*}{ Phase I a } \\
\hline 1100 & \multirow{2}{*}{ III } & & \multirow{2}{*}{ III } & \\
\hline 1200 & & D & & \\
\hline 1300 & \multirow{3}{*}{ II } & & \multirow{3}{*}{ II } & \\
\hline 1400 & & C & & \\
\hline 1500 & & B & & \\
\hline 1600 & & & & \\
\hline 1700 & \multirow{3}{*}{ I } & \multirow{6}{*}{ A } & \multirow{3}{*}{ I } & \\
\hline 1800 & & & & \\
\hline 1900 & & & & \\
\hline 2000 & & & & \\
\hline 2100 & & & & \\
\hline 2200 & & & & \\
\hline
\end{tabular}

Table 1. Chronological sequence - Western and Central Europe, Northern Europe, Poland and the Ruda site.

It is located $1.5 \mathrm{~km}$ south-west of Sztynwag. ${ }^{6}$ At $0.6 \mathrm{~km}$ south of the site there is a steep slope of the Vistula valley elevating up to 40 metres. Two tributaries, draining the area, flow east and west from the site, within about $0.2 \mathrm{~km}$. The watercourse on the western side of the site flows into a deep erosion valley, which begins near Trzebiełuch $(2.5 \mathrm{~km}$ to the south-west from the southern end of the site). The "eastern" watercourse originates at the foot of the upland slope at the mouth of a ravine valley. ${ }^{7}$

Four habitation phases were distinguished, based on the radiocarbon dating, the styles of vessels and mutual relations of features. ${ }^{8}$ The earliest phase $-\mathrm{Ia}$, is dated to between the second half of the $3^{\text {rd }}$ and the first half of the $4^{\text {th }}$ period of the Bronze Age. The classical Phase Ib is dated to between the $4^{\text {th }}$ period of the Bronze Age and the first part of the $5^{\text {th }}$ period. The third habitation phase - II, is dated to the end of the $5^{\text {th }}$ period of the Bronze Age and the Hallstatt period $\left(\mathrm{Ha} \mathrm{C}_{1}-\mathrm{Ha} \mathrm{D}_{2}\right)$. The fourth phase - II/III (phase of Lusatian-Pomeranian Culture transformation) is dated to $\mathrm{Ha} \mathrm{D}_{3}$. Based on fragments of ceramic vessels, bronze objects and their analogies, the chronology of this site can be narrowed

\footnotetext{
${ }^{6}$ Bienias 2006, 11.

${ }^{7}$ Bienias 2006, 10.

${ }^{8}$ Rembisz-Lubiejewska 2015, 118-126.
}

down to the turn of the $4^{\text {th }} / 5^{\text {th }}$ period of the Bronze Age, half of $5^{\text {th }}$ period and the beginning of Phase Ha C. ${ }^{9}$ A series of $\mathrm{C}^{14}$ dates obtained for some archaeological objects, allow to state that the settlement was used between 900600 BC. ${ }^{10}$ In stratigraphic relations, the earliest phase related to the Lusatian Culture is Cultural Layer I, formed over a destroyed Neolithic level, on a small hill in the northern part of the site. Its origin can be associated with younger periods of the Bronze Age. Also in these periods, although slightly later, the Cultural Layer II accumulated. Cultural Layer III probably formed already in early periods of the Iron Age (Table 1). ${ }^{11}$

\footnotetext{
${ }^{9}$ The periodisation system used in Poland for archaeological materials from the Bronze and Iron Age is based on the chronology of Montelius (1900) and Reinecke (1924), adapted by Kostrzewski, Chmielewski and Jażdżewski (Kostrzewski et al. 1965). A division into 5 periods was adopted for archaeological materials from Poland, from the Bronze Age, with the Younger Bronze Age covering the third and the fifth periods according to Montelius. However, for the beginning of the Iron Age a division based on the Reinecke scheme was adopted, where Phases $\mathrm{Ha} \mathrm{C}_{1-2}, \mathrm{Ha} \mathrm{D}_{1-2}$ and $\mathrm{Ha} \mathrm{D}_{3} / \mathrm{LT} \mathrm{A}$ are distinguished.

${ }^{10}$ Kowaljuk 2006, 25-26; Rembisz 2006, 398.

${ }^{11}$ Rembisz 2006, 172.
} 


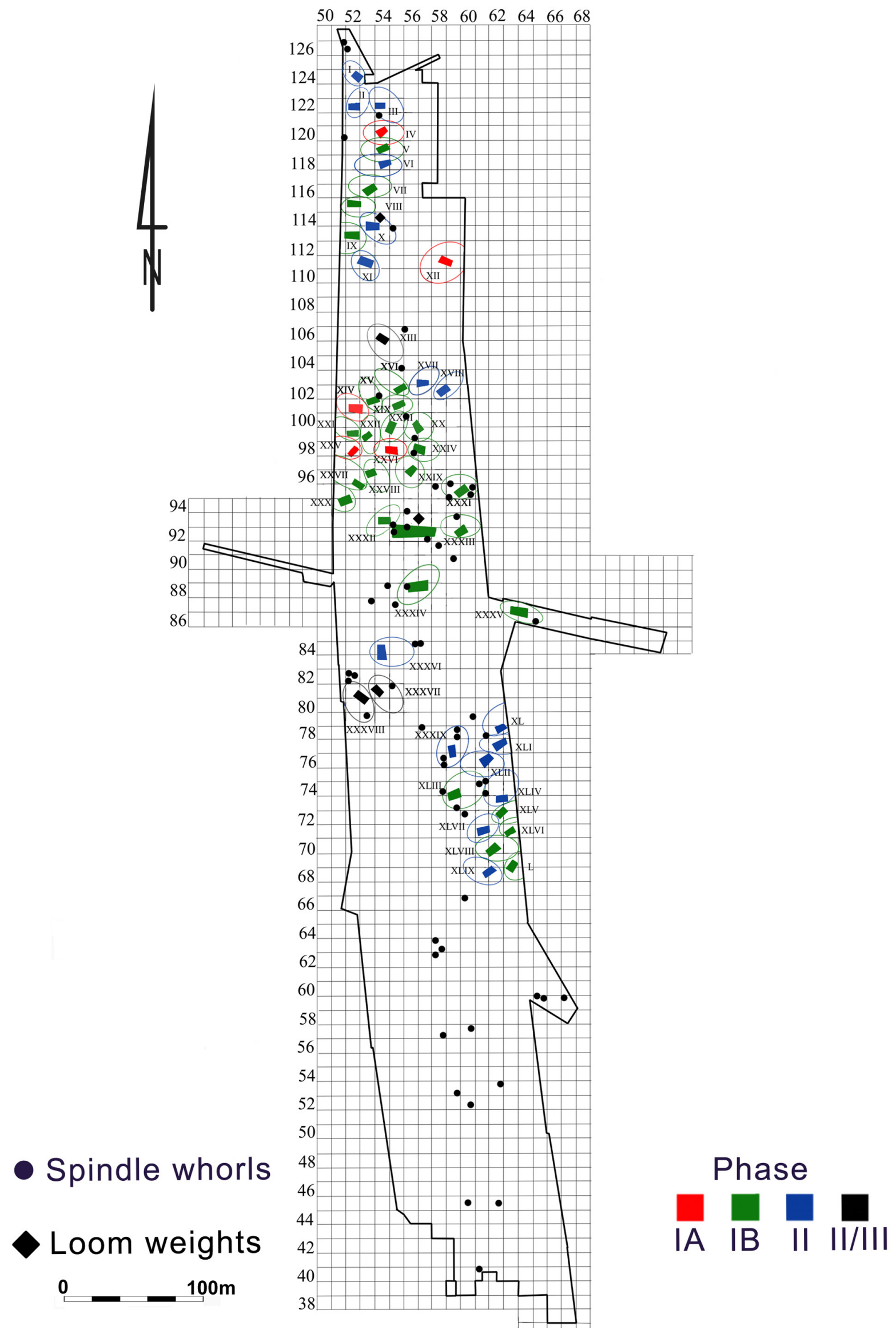

Fig. 1. Distribution of spindle whorls and loom weights from Ruda, Site 3-6. Drawing M. Przymorska-Sztuczka after Rembisz-Lubiejewska 2015, Fig. 52. 
MAGDALENA PRZYMORSKA-SZTUCZKA

\begin{tabular}{|c|c|c|c|c|c|c|}
\hline \begin{tabular}{|l|} 
No \\
\end{tabular} & Inventory No & Shape* & Weight [g] & Diameter $[\mathrm{cm}]$ & Height $[\mathrm{cm}]$ & Perforation $[\mathrm{cm}]$ \\
\hline 1 & $105 / 00 \mathrm{~A}$ & Discoid & 8 & - & 0.65 & - \\
\hline 2 & $113 / 00 \mathrm{~A}$ & Discoid & 6 & - & 0.65 & - \\
\hline 3 & $124 / 00 \mathrm{~A}$ & Star-shaped & 12 & 4 & 1.5 & 0.3 \\
\hline 4 & $129 / 00 \mathrm{~A}$ & Discoid & $18(54)$ & $2.7(5.4)$ & 1.6 & - \\
\hline 5 & $21 / 00 \mathrm{~B}$ & Oval (intact) & 24 & 3.8 & 1.6 & 0.6 \\
\hline 6 & $24 / 00 \mathrm{~B}$ & Spherical (intact) & 15 & 3.3 & 1.3 & 0.4 \\
\hline 7 & $26 / 00 \mathrm{~B}$ & Conical (intact) & 15 & 3.4 & 1.5 & 0.4 \\
\hline 8 & $27 / 00 \mathrm{~B}$ & Oval & $7(14)$ & $1.7(3.2)$ & 2.3 & - \\
\hline 9 & $29 / 00 \mathrm{~B}$ & Discoid & 6 & - & 0.6 & - \\
\hline 10 & $32 / 00 \mathrm{~B}$ & Conical (intact) & 13 & 3.1 & 1.2 & 0.45 \\
\hline 11 & 1/01B & Discoid & $15(60)$ & $3.7(7.4)$ & 1.3 & 0.6 \\
\hline 12 & $2 / 01 \mathrm{~B}$ & Conical & $10(20)$ & $1.8(3.6)$ & 1.4 & 0.4 \\
\hline 13 & $3 / 01 \mathrm{~B}$ & Discoid (intact) & 17 & 3.5 & 1.4 & 0.5 \\
\hline 14 & $4 / 01 \mathrm{~B}$ & Conical (intact) & 15 & 3.2 & 1.3 & 0.5 \\
\hline 15 & $7 / 01 \mathrm{~B}$ & Discoid & $26(52)$ & 5.8 & 1.8 & - \\
\hline 16 & $11 / 01 \mathrm{~B}$ & Discoid (intact) & 9 & 3 & 1 & 0.3 \\
\hline 17 & 48/01B & Discoid* & - & - & - & - \\
\hline 18 & 49/01B & Discoid & $14(70)$ & $3(6)$ & 1.8 & $?$ \\
\hline 19 & 50/01B & Discoid* & - & - & - & - \\
\hline 20 & 9/00C & Oval (intact) & 20 & 3.5 & 1.5 & 0.6 \\
\hline 21 & $10 / 00 \mathrm{C}$ & Discoid* & - & - & - & - \\
\hline 22 & $23 / 01 \mathrm{C}$ & Discoid* & - & - & - & - \\
\hline 23 & $29 / 01 C$ & Discoid & $23(50)$ & $3.3(6.6)$ & 1.5 & 0.8 \\
\hline 24 & $31 / 01 \mathrm{C}$ & Oval (intact) & 27 & 3.7 & 2 & 0.6 \\
\hline 25 & $40 / 01 \mathrm{C}$ & Oval & $13(26)$ & 3.1 & 1.7 & 0.6 \\
\hline 26 & $41 / 01 \mathrm{C}$ & Starshaped & 15 & 4.3 & 1.7 & 0.5 \\
\hline 27 & $42 / 01 \mathrm{C}$ & Conical & $5(15)$ & $1.7(3.4)$ & 1.3 & 0.3 \\
\hline 28 & $49 / 01 \mathrm{C}$ & Biconial (intact) & 11 & 3.2 & 1.3 & 0.4 \\
\hline 29 & $50 / 01 \mathrm{C}$ & Oval (intact) & 14 & 2.8 & 1.7 & 0.6 \\
\hline 30 & $58 / 01 \mathrm{C}$ & Discoid & 11 & 3.6 & 0.8 & - \\
\hline 31 & 6/00D & Oval (intact) & 9 & 2.8 & 1.4 & 0.4 \\
\hline 32 & $8 / 00 \mathrm{D}$ & Discoid (intact) & 40 & 5.3 & 1.5 & 0.6 \\
\hline 33 & $78 / 01 \mathrm{D}$ & Discoid & $18(36)$ & $3(6)$ & 1.2 & 0.5 \\
\hline 34 & $105 / 01 \mathrm{D}$ & Discoid* & - & - & - & - \\
\hline 35 & 106/01D & Discoid* & - & - & - & - \\
\hline 36 & 181/01D & Oval & $8(16)$ & 3.4 & 1 & 0.6 \\
\hline 37 & $182 / 01 \mathrm{D}$ & Discoid & 4 & - & 0.7 & - \\
\hline 38 & $332 / 01 \mathrm{D}$ & Discoid & 9 & $2.4(4.8)$ & 1.3 & - \\
\hline 39 & $10 / 02 \mathrm{E}$ & Discoid & $18(36)$ & 6.3 & 1.25 & 0.5 \\
\hline 40 & $23 / 02 \mathrm{E}$ & Discoid & $8(16)$ & $2.1(4.2)$ & 0.8 & 0.5 \\
\hline 41 & $30 / 02 \mathrm{E}$ & Discoid & $15(60)$ & $2.5(5)$ & 1 & 0.7 \\
\hline 42 & $32 / 002 \mathrm{E}$ & Discoid** & - & - & - & - \\
\hline 43 & $33 / 02 \mathrm{E}$ & Discoid** & - & - & - & - \\
\hline 44 & $35 / 02 \mathrm{E}$ & Oval & 6 & $2(4)$ & 1.1 & - \\
\hline 45 & $35 / 02 \mathrm{~F}$ & Discoid & $17(54)$ & $2.7(5.4)$ & 1 & 0.6 \\
\hline 46 & $103 / 02 \mathrm{~F}$ & Conical & $6(12)$ & $1.9(3.8)$ & 1.4 & 0.4 \\
\hline 47 & $108 / 02 \mathrm{~F}$ & Discoid (intact) & 15 & 3.5 & 1.1 & 0.4 \\
\hline 48 & $122 / 02 \mathrm{~F}$ & Discoid (intact) & 33 & 4.5 & 1.4 & 0.6 \\
\hline 49 & $154 / 02 \mathrm{~F}$ & Discoid & 10 & - & 1.3 & - \\
\hline 50 & $158 / 02 \mathrm{~F}$ & Discoid & 4 & $2.1(4.2)$ & 0.8 & - \\
\hline 51 & $159 / 02 \mathrm{~F}$ & Discoid & $10(50)$ & $2.5(5)$ & 1.1 & - \\
\hline 52 & $162 / 02 \mathrm{~F}$ & Discoid & $12(48)$ & $2.7(5.4)$ & 1.3 & - \\
\hline 53 & $162 / 02 \mathrm{~F}$ & Discoid & 5 & - & 1 & - \\
\hline 54 & $164 / 02 \mathrm{~F}$ & Discoid & 5 & $2.5(5)$ & 1 & - \\
\hline 55 & $165 / 02 \mathrm{~F}$ & Discoid & 7 & - & 1.1 & - \\
\hline 56 & $166 / 02 \mathrm{~F}$ & Discoid & 9 & - & 0.6 & - \\
\hline 57 & $171 / 02 \mathrm{~F}$ & Discoid & $13(65)$ & $3.1(6.2)$ & 1.4 & - \\
\hline 58 & $2 / 02 \mathrm{G}$ & Oval & $9(18)$ & $1.8(3.6)$ & 2.2 & 0.5 \\
\hline 59 & $18 / 02 \mathrm{G}$ & Discoid (intact) & 11 & 3.2 & 1 & 0.7 \\
\hline 60 & $29 / 02 \mathrm{G}$ & Discoid & 8 & - & 0.7 & - \\
\hline 61 & $1 / 02 \mathrm{H}$ & Discoid & $9(45)$ & $2.5(5)$ & 1.15 & - \\
\hline 62 & $17 / 02 \mathrm{H}$ & Oval & $19(38)$ & $2.3(4.6)$ & 1.7 & 0.8 \\
\hline 63 & $36 / 02 \mathrm{H}$ & Discoid & 4 & $2.5(5)$ & 0.65 & - \\
\hline
\end{tabular}

* Spindle whorls have mostly been preserved in fragments. If the spindle whorl was intact this information is provided in the table in brackets. ** The artefact was lost.

Table 2. Technical characteristics of the spindle whorls from Ruda, Site 3-6. 


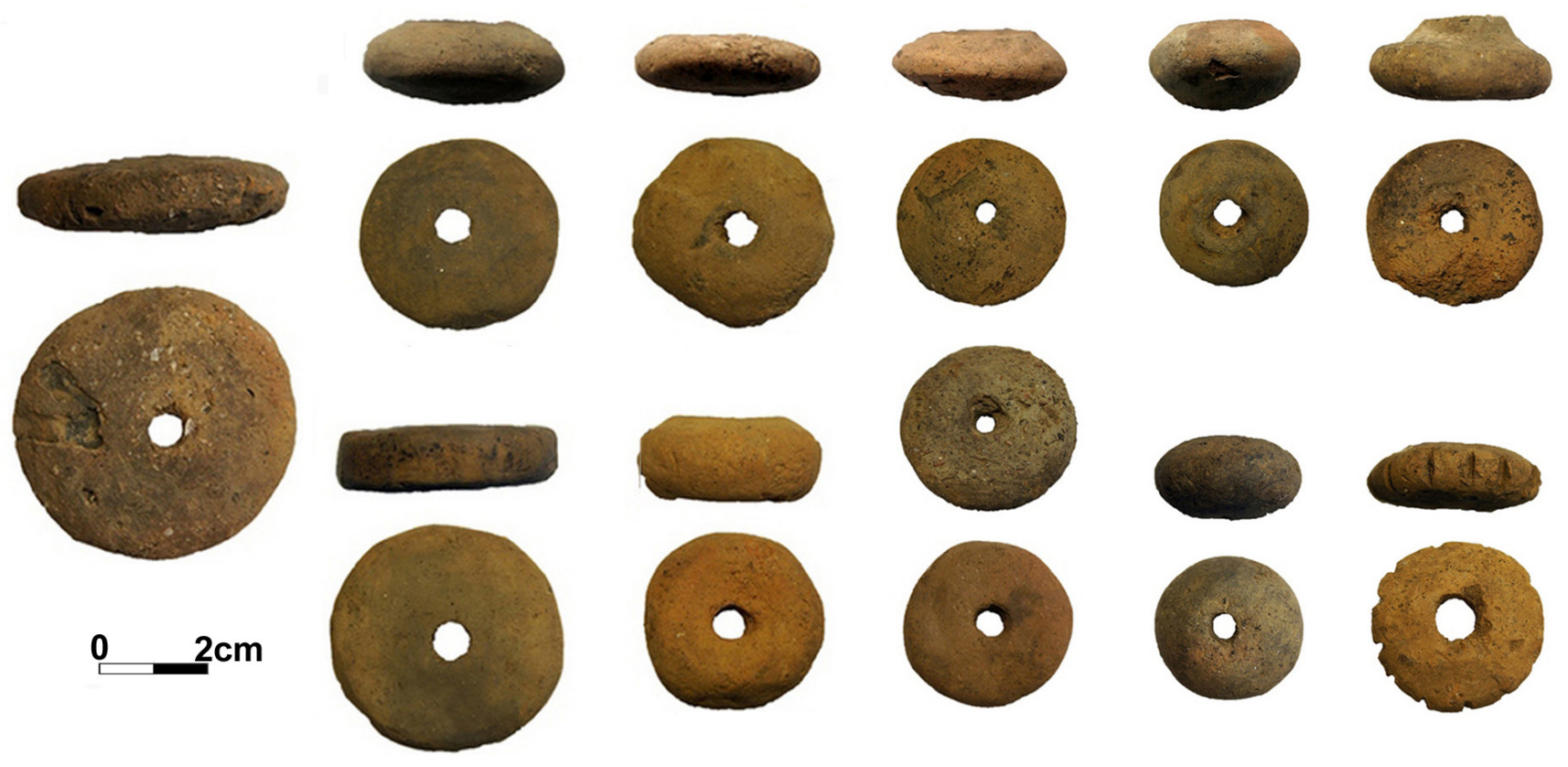

Fig. 2. Spindle whorls from Ruda, Site 3-6. Photos M. Przymorska-Sztuczka.

Features of the Lusatian Culture at the Ruda 3-6 site were found in distinct clusters. Several dozen enclosures were distinguished, which included residential buildings and storage pits (Fig. 1). The first cluster of features was discovered in the northern part of the site, at its western boundary. Within its range, outlines of 13 enclosures which, semicircularly surrounded the square with storage pits, were reconstructed. ${ }^{12}$ The lengths of their walls ranged from 6 to $12 \mathrm{~m}$. Remains of the second settlement cluster were located several metres further to the south. It was made up of a dozen or so enclosures, with no clear arrangement. These enclosures included traces of post structures, storage pits and fences. ${ }^{13}$ The third area was distinguished in the southern part of Cultural Layer I, a natural layer, and in the northern part of Cultural Layer II. Also in this case, it was possible to isolate several residential buildings and storage pits next to them. These features were located around a small hill. ${ }^{14}$ Locations of the clusters on the northern, western and southern sides of the hill suggest the presence of settlement traces also on its eastern slope (outside the development area that has not been excavated). ${ }^{15}$ The last, fourth cluster of residential facilities was discovered in the southern part of Cultural Layer II. Preserved traces of buildings were discovered in a semicircular arrangement at the foot of a dune slope. ${ }^{16}$ Also in this case, it was suggested that the fourth cluster went well beyond the excavated area. This was indicated by its location and partial preservation at

\footnotetext{
${ }^{12}$ Rembisz 2006, 168.

${ }^{13}$ Rembisz 2006, 169.

${ }^{14}$ Rembisz 2006, 169.

${ }^{15}$ Rembisz 2006, 169

${ }^{16}$ Rembisz 2006, 169.
}
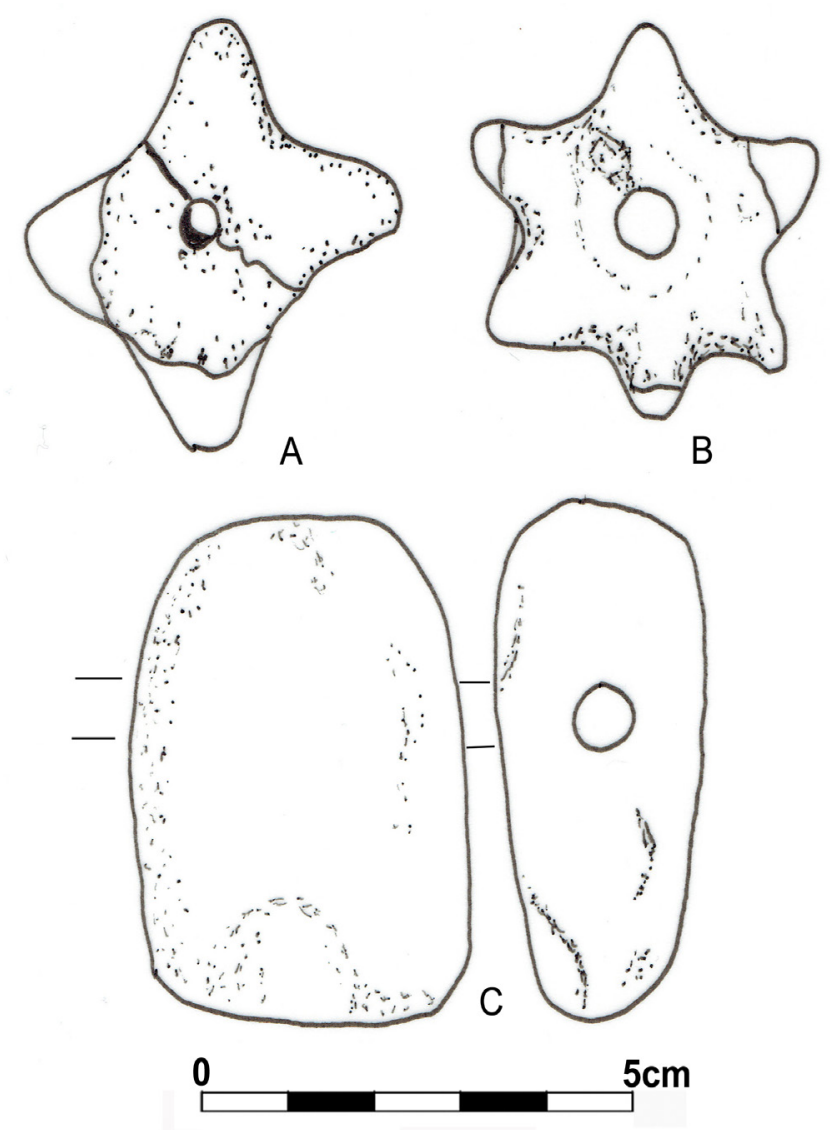

Fig. 3. A-B - star-shaped spindle whorls; $\mathrm{C}$ - potential loom weight. Drawing M. Przymorska-Sztuczka after Rembisz-Lubiejewska 2015, Fig. 17. 


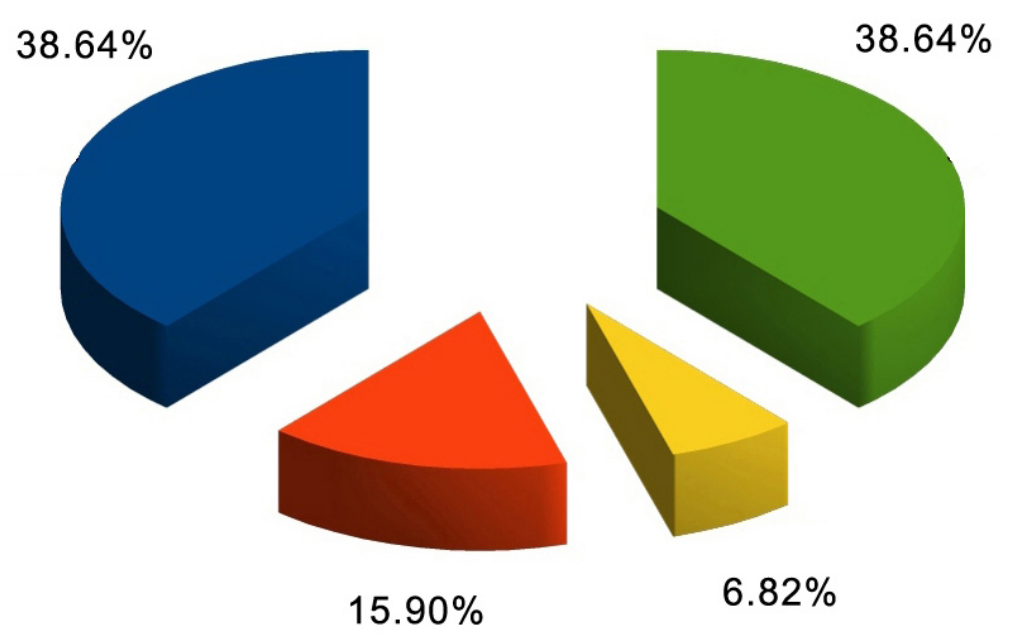
Group I - weight 8-19 g;
diameter $2.5-5 \mathrm{~cm}$
Group II - weight 20-35 g;
diameter $3-4.9 \mathrm{~cm}$

\author{
Group III - weight 20-35 g; \\ diameter $5-7 \mathrm{~cm}$ \\ Group IV - weight 36-60 g; \\ diameter $5-7.5 \mathrm{~cm}$
}

Fig. 4. Distribution of spindle whorls from Ruda, Site 3-6, according to their weight and diameter. Elaborated by M. Przymorska-Sztuczka.

the eastern boundary of the explored area. ${ }^{17}$ Not all households and settlement clusters functioned at the same time.

\section{Archaeological sources for textile production at Ruda}

The assemblage of artefacts which will be discussed in detail in this paper comprises 63 spindle whorls, two objects interpreted as loom weights, and Feature $1351 \mathrm{~F}$ interpreted as remains of a warp-weighted loom, discovered at the Ruda site. ${ }^{18}$ Spindle whorls have been preserved mostly in fragments. In Table 2, numbers in brackets are reconstructed weights and diameters.

\section{Spindle whorls}

The most numerous spindle whorls occurred in the fills of the features discovered in individual enclosures or next to them in the Cultural Layers I, II and IV (Fig. 1). ${ }^{19}$ At the same time, the cultural affiliation of three of them is debatable since other finds, namely vessels of the Lusatian Culture, the Globular Amphora Culture (Feature 708C) and the Pomeranian Culture (Features 435B, 803C), were found in the same fills. Five spindle whorls were also excavated from the "Lusatian" cultural layers. Most of discovered spindle whorls (Fig. 2) at Ruda are discoid, with slightly rounded or straight

${ }^{17}$ Rembisz 2006, 169.

${ }^{18}$ Rembisz 2006, 349.

${ }^{19}$ Features 14A, 186A, 280A, 330B, 377B, 408B, 426B, 435B, $475 \mathrm{~B}, 573 \mathrm{~B}, 732 \mathrm{~B}, 791 \mathrm{~B}, 858 \mathrm{~B}, 508 \mathrm{C}, 580 \mathrm{C}, 700 \mathrm{C}, 708 \mathrm{C}, 803 \mathrm{C}$, $804 \mathrm{C}, 250 \mathrm{D}, 217 \mathrm{D}, 1165 \mathrm{D}, 1315 \mathrm{D}, 13 \mathrm{E}, 160 \mathrm{E}, 163 \mathrm{E}, 224 \mathrm{E}, 12 \mathrm{~F}$, $152 \mathrm{~F}, 158 \mathrm{~F}, 479 \mathrm{~F}, 688 \mathrm{~F}, 736 \mathrm{~F}, 1177 \mathrm{~F}, 1316 \mathrm{~F}, 1335 \mathrm{~F}, 1382 \mathrm{~F}, 1460 \mathrm{~F}$, $1483 \mathrm{~F}, 1541 \mathrm{~F}, 1555 \mathrm{~F}, 12 \mathrm{H}$. edges. Their diameters range between 3 to $7.4 \mathrm{~cm}$, their heights are from 0.6 to $1.5 \mathrm{~cm}$, and their weights are from 9 to $70 \mathrm{~g}$. Fewer objects have oval or double-conical cross-sections. Their diameters are from 2.8 to $3.8 \mathrm{~cm}$, their heights are from 1.3 to $2.3 \mathrm{~cm}$, and their weights are from 9 to $27 \mathrm{~g}$.

Spindle whorls from Ruda do not differ from others spindle whorls commonly found in the settlements from the Late Bronze Age and the Early Iron Age, for example from Biskupin, ${ }^{20}$ Grodno, ${ }^{21}$ Gzin ${ }^{22}$ and Smuszewo. ${ }^{23}$

Two "horned" or "starry" spindle whorls with four and six projections are of unique shape. One is fragmentarily preserved, the other is complete with slightly damaged ends (Fig. 3:A, B). Similar objects (two items), also interpreted as spindle whorls, were discovered in the settlement of the Lusatian Culture at Grzybiany near Legnica. ${ }^{24}$ They were formed from flattened clay balls with a central hole, and the projections on the edge were made using finger nails. ${ }^{25}$

In general, for textile production it can be stated that a proper selection of a spindle whorl for a spindle is conditioned by several factors (including raw material and purpose of the yarn for weft or warp), which results in a variety of shapes and weights of spindle whorls discovered at archaeological sites. ${ }^{26}$ Are these variations of spindle size and whorl type connected

\footnotetext{
${ }^{20}$ Szafrański 1950, 132.

${ }^{21}$ Gackowski 2009, 30.

${ }^{22}$ Chudziakowa 1992, 45.

${ }^{23}$ Durczewski 1985, 46-47.

${ }^{24}$ Sielicka 2014, 303.

${ }^{25}$ Sielicka 2014, 303.

${ }^{26}$ Chmielewski and Gardyński 2009, 146.
} 

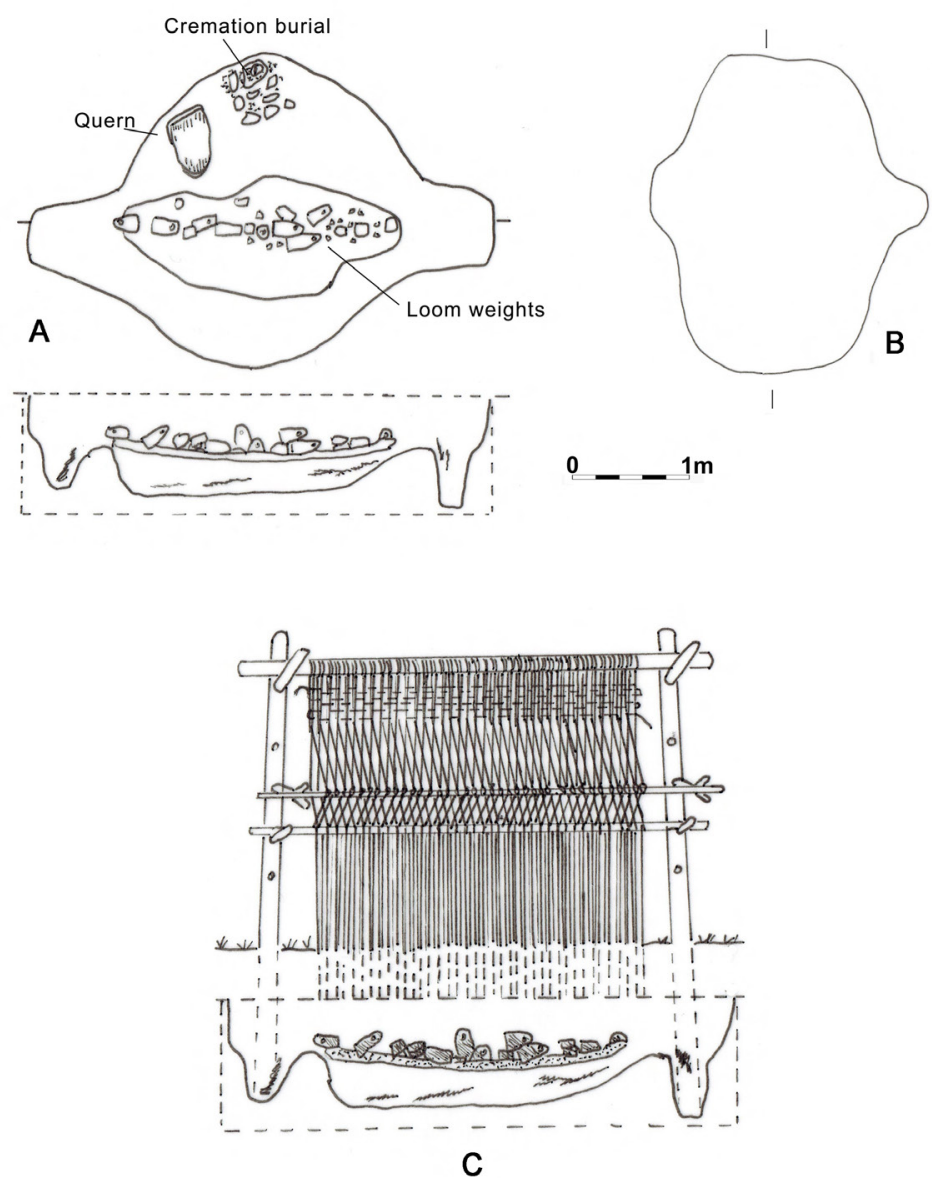

Fig. 5. A - plan and section of the remains of a warp-weighted loom from Wallwitz; B - outline of archaeological Feature 1351F from Ruda; C - reconstruction of a warp-weighted loom from Wallwitz. Drawing M. Przymorska-Sztuczka: A - after Stahlhofen 1978, Fig. 1; B - after Rembisz-Lubiejewska 2015, Fig. 48; C - after Stahlhofen 1978, Fig. 2.

to variations in thread type, thickness or thread production? To answer this question, a number of experiments were carried out in centres testing archaeological textiles. The main assumption was to determine the amount of influence of the tool on the spinning process with a hand-spindle. There are different considerations by different scholars about the interaction between whorl size/shape/weight and the obtained thread. ${ }^{27}$ To some scholars, the same type of threads could have been made by a larger range of whorl weights and diameter. ${ }^{28}$ In her systematisation of these factors, Ch. Kimbrough divided spindle whorls into four groups. ${ }^{29}$ The first group included light spindle whorls which weighed $8-19 \mathrm{~g}$ and were $2.5-5 \mathrm{~cm}$ in diameter. Such whorls were used for spinning thin threads of fine and short woollen or goat fibres. The second group consists of spindle whorls weighing 20-35 $\mathrm{g}$ and being 3-4.9 cm

${ }^{27}$ Grömer 2005, 107-116; Mårtensson et al. 2005-2006; Mårtensson 2007, 97-106; Kania 2013, 11-29; Andresson-Strand and Nosch 2015, 139-151.

${ }^{28}$ Grömer 2005; Kania 2013.

${ }^{29}$ Kimbrough 2006, 136-137. in diameter. These were used for making thin threads of long staple wool. The third group included items of the same weight as in the second group (20-35 g), but with a diameter of $5-7 \mathrm{~cm}$. They were used for spinning threads of short wool fibres of average thickness. The last fourth group includes the heaviest and largest spindle whorls, weighing 36-60 $\mathrm{g}$ and being $5-7.5 \mathrm{~cm}$ in diameter, which were used for making linen threads or medium quality, thick woollen threads, or for plying several threads together. ${ }^{30}$ Considering the above criteria, most of the spindle whorls discovered in the settlement at Ruda belong to the first and fourth groups. The least represented are those belonging to the third group (Fig. 4).

Six spindle whorls were discovered very close to a structure identified as an aisled building at Ruda. Structures of this kind were characteristic for the next habitation phase of the settlement. ${ }^{31}$ They were located around a small hill, and were even up to 200 square metres large. The remaining concentration of spindle whorls, from three to five pieces,

\footnotetext{
${ }^{30}$ Kimbrough 2006, 136.

${ }^{31}$ Rembisz 2006, 389.
} 
was discovered within the limits of single-building Enclosures 1, 33, 34, 36, 38, 39, 42 and 43. Household 31 (Feature $1460 \mathrm{~F}$ ) was interpreted as a bronze workshop, on the basis of finds of foundry moulds and fragments of bronze items. ${ }^{32}$ Five spindle whorls were discovered in its immediate vicinity. The above data suggests that spinning was carried out in the spare time and while performing other activities within the households, such as preparing a meal or helping in a foundry workshop.

\section{Loom weights}

Items interpreted as loom weights were discovered in two features $-870 \mathrm{D}$ and $1351 \mathrm{~F}$. Unfortunately, the artefacts described here were lost, and for that reason the author was not able to study them. The completely preserved item made of clay $(3 \times 4 \times 8 \mathrm{~cm})$ from Feature $1351 \mathrm{~F}$ looks like a stone $\operatorname{axe}^{33}$ (Fig. 3:C). The unusual (for a loom weight) location of the hole along its widest and not the narrowest plane, speaks against the interpretation of this item as a loom weight. ${ }^{34}$ Although similar items discovered at Grodno and Sobiejuchy, ${ }^{35}$ were also interpreted as loom weights, their functions remain debatable. Nevertheless the above mentioned object from Ruda was discovered in the feature interpreted as a remains of a vertical loom. Concerning the second item, originating from Feature 870D and discovered near Enclosure 10 , only a small fragment of the base was preserved. The weight had probably a pyramidal form. This shape was widespread in the Lusatian Culture. Several similar weights have been discovered, among others, at Biskupin, ${ }^{36}$ Smuszewo, ${ }^{37}$ and Sobiejuchy. ${ }^{38}$

The afore-mentioned Feature $1351 \mathrm{~F}$ had an oval outline (Fig. 5:B) in horizontal view with symmetrically arranged lateral projections (pole/loom support frame traces). The length of this feature was $2 \mathrm{~m}$, and the width was $1.48 \mathrm{~m}$. Its interpretation as remains of a warp-weighted loom was based on two premises. The first one was the discovery of an item interpreted as a loom weight together with two stones in its fill. These stones could have also served as weights. ${ }^{39}$ The second premise concerns the feature from Wallwitz in Saxony. This feature belonged to the German group of the Urnfield Culture and was dated to the $4^{\text {th }}$ period of the Bronze Age. This archaeological feature was analogous to that from Ruda with regard to its projection and the cross-section. ${ }^{40}$

\footnotetext{
${ }^{32}$ Rembisz 2006, 163.

${ }^{33}$ Rembisz 2006, 349.

${ }^{34}$ The author would like to thank Joanna Słomska MA, from the Centre for Research on Ancient Technologies of the Institute of Archaeology and Ethnology of the Polish Academy of Sciences for consultations.

${ }^{35}$ Rembisz 2006, 115.

${ }^{36}$ Szafrański 1950, 133.

${ }^{37}$ Durczewski 1985, 42-46.

${ }^{38}$ Harding et al. 2004, 61.

${ }^{39}$ Rembisz-Lubiejewska 2015, 35.

${ }^{40}$ Stahlhofen 1978, 180; Rembisz-Lubiejewska 2015, 35.
}

In addition to the settlement at Wallwitz, similar items were discovered at $\mathrm{Zedau}^{41}$ and at Berlin-Buch and Lichterflede. ${ }^{42}$ Loom weights arranged in rows were found in their fills. The length of the row of weights at Zedau was $59 \mathrm{~cm}$, whereas at Wallwitz, a row of 27 weights occupied a space of 2.45 metres (Fig. 5:A). Together with post holes, the feature had a total length of 3 metres. ${ }^{43}$ Considering the above data and the fact that some traits of Feature $1351 \mathrm{~F}$ were analogous to those listed above from Germany, the author also inclines to the interpretation of this construction as remains of a vertical loom (Fig. 5:C), despite the afore-mentioned doubts concerning the function of the clay object discovered in its fill.

\section{Archaeobotanical and archeozoological sources}

Plant microartefacts of flax (Linum usitatissimum L.) seeds and nettle fruits (Urtica dioica $\mathrm{L}$. $)^{44}$ were discovered in soil samples from Features 354, 902 and 1140 at Ruda. Flax seeds discovered at Ruda could be used for sowing. While the use of flax in the production of fabrics is undeniable, although it should be remembered that oil extraction from seeds was also very likely, ${ }^{45}$ the use of nettles for this purpose is sometimes debatable. Nettle is also a fibrous plant, although it is currently considered a weed and is used only for healing purposes. Nettle can help out as an herbal alternative supporting healthful function of the kidneys, liver, digestive tract, and overall metabolism while strengthening the constitution. ${ }^{46}$ A direct argument for the use of nettles for textile purposes could be fabrics made of it, but they are extremely rare. According to Chmielewski ${ }^{47}$ the earliest finds of a nettle fibre, are pseudomorphs from a grave of the Polgár Culture at Hódmezővásárhely-Gorzsa and from the site of the Ertebølle Culture at Skjoldnæs. ${ }^{48}$ The first "nettle" fabric in Northern Europe comes from a burial discovered at Lusehøj in Voldtofte in Denmark, ${ }^{14} \mathrm{C}$ dated to $940-750 \mathrm{BC} .{ }^{49}$ Thanks to the strontium isotope studies it was established that the nettle, used to make this fabric, came from Central Europe, from the region of Carinthia/Styria in Austria. ${ }^{50}$ As shown by experimental work, ${ }^{51}$ nettle can also provide high-quality fibres. Although there is no direct evidence for the use of nettle for textile purposes at Ruda, we cannot reject its possible use for this purpose among the "Lusatian" communities.

Processing of plant fibres should be addressed at this point. One of necessary steps in obtaining fibres is the retting

\footnotetext{
${ }^{41}$ Horst 1985, 105.

${ }^{42}$ Harding 2000, 258.

${ }^{43}$ Harding 2000, 258.

${ }^{44}$ Kasprzyk and Polcyn 2006, 47.

${ }^{45}$ Barber 1991, 12.

${ }^{46}$ Dąbrowski 2010, 48.

${ }^{47}$ The author of this article is more inclined to interpret these fibres as plant fibres.

${ }^{48}$ Chmielewski 2009, 27.

${ }^{49}$ Bergfjord et al. 2012, 1-2.

${ }^{50}$ Bergfjord et al. 2012, 3 .

${ }^{51}$ Brown 2017; http://www.nettlesfortextiles.org.uk/wp/.
} 
process. It consists in arranging flax bundles directly on the field and exposing them to the forces of nature (so called "dew retting" method) or placing them directly in water (lakes or rivers) or in retting pits. ${ }^{52}$ This process, however, causes a very unpleasant smell (harmful butyric acid is produced) and contaminates water. ${ }^{53}$ Soaking in retting pits had to take place either on the periphery of settlements or outside their borders. ${ }^{54}$

In the case of Ruda, soaking flax in the stream or in vats located directly next to it seems the most likely. At about 200 metres to the east and west of the site, there are two watercourses, draining the area of the upland. ${ }^{55}$ It is a distance that can be easily walked, even several times a day. Preparation of flax fibres for further processing probably took place at one of these two streams rather than directly around the settlement.

The retting stage did not leave traces in the archaeological material if it was carried out in the field or in water reservoirs. However, retting vats are known from Europe. Fifty-two such features were discovered at Frydnelund in Denmark, dating back to the years between 800 and 350 BC. ${ }^{56}$ Remains of flax were also found in pits in Great Britain in the Bronze Age settlement at West Row Fen. ${ }^{57}$ Similar features were also found in Poland. A feature interpreted as a retting pit and radiocarbon dated to 360-200 BC was discovered during archaeological research at Brońsko in Greater Poland. ${ }^{58}$ Flax bundles were found at its bottom. The hypothesis of retting pits was also proposed by Karol Dzięgielewski in relation to so-called "crevice pits" at Brzezie, Modlnica and Podłęże near Cracow from the Bronze Age and the Early Iron Age. ${ }^{59}$ Other vats from Poland were discovered at the site of the Przeworsk Culture at Daniszew, ${ }^{60}$ Karczyn $^{61}$ and Kolonia Orenice ${ }^{62}$. These are dated to $2^{\text {nd }}$ and $3^{\text {rd }}$ century AD.

The second category of sources, indirectly indicating the type of textile raw materials used in the settlement at Ruda, are the remains of sheep. Archaeozoological analysis shows that cattle and then horse appeared most often at the site. The sheep appeared as third. ${ }^{63}$ The slaughter age and sex allow to speculate about its intended use. Sheep raised for meat are slaughtered in a different way and at a different age from those kept for producing wool. ${ }^{64}$ The herd bred for the purpose of obtaining milk and wool consists mainly of adult

\footnotetext{
${ }^{52}$ Poczobutt 1960, 8.

${ }^{53}$ Troldtoft Andresen and Karg 2011, 1.

${ }^{54}$ Dzięgielewski 2011, 123.

${ }^{55}$ Bienias 2006, 10.

${ }^{56}$ Troldtoft Andresen and Karg 2011, 3-4.

${ }^{57}$ Martin and Murphy 1988, 355.

${ }^{58}$ Pawlak and Pawlak 2008, 220.

${ }^{59}$ Dzięgielewski 2011, 104.

${ }^{60}$ Żychliński 2007, 150.

${ }^{61}$ Bednarczyk 2000, 79.

${ }^{62}$ Siciński 2008, 79

${ }^{63}$ Makowiecki 2006, 40.

${ }^{64}$ Becker et al. 2016, 122.
}

sheep and castrated males. ${ }^{65}$ At Ruda, the slaughter age of this animal was determined on 8 individuals and was estimated at 3-4 years. This indicates the use of this species for harvesting wool fleece and milk. ${ }^{66}$

\section{Organisation of textile production at Ruda}

The issue of the organisation of textile production and the level of its specialisation in the Late Bronze Age and the Early Iron Age in the area of present-day Poland is not sufficiently well researched. These issues were not previously the subject of archaeological interest. Recently, research on broadly understood textile economy has been conducted by Anna Grossmann, Joanna Słomska and Łukasz Antosik, ${ }^{67}$ and the author of this article.

According to Costin, ${ }^{68}$ production and specialisation are not identical. Production is making useful things from available raw materials. Specialisation, on the other hand, is a way of organising production. What distinguishes specialised and non-specialised production is regular, repetitive production or offering services in exchange for something else. There are two levels of specialisation - low and high. The less people produce a given product in relation to the number of buyers, the higher the level of specialisation. ${ }^{69}$ The production itself has also several levels. These were best characterised by Eva Andersson Strand. ${ }^{70}$ The lowest rank is household production. It is characterised by production satisfying its own needs. Community members have the necessary knowledge and skills, and raw materials are widely available. Household industry is a higher level of production. The scale of production goes beyond the needs of the producers but still is organised at the household level. Surplus is spent on exchange, trade or tribute. The next level is attached specialist production. At this stage, products are made by specialists who are supported by or dependent on the patron and work mainly on a full-time basis. As a result, the manufactured items are of better quality. The highest level is specialised production in workshops, where standardised products are intended for trade. In this case, the amount of manufactured items is high. There is also a high demand among members of a given community.

Textile craft in the Bronze Age in Central Europe was organised on two levels - as household production for own use and as household industry. ${ }^{71}$ It cannot be excluded that in more and more stratified communities during the Bronze Age textiles could have been subject of exchange. ${ }^{72}$ The situation in the Early Iron Age is different. During this period there were deep social changes due to the appearance of a new material - iron. It has its manifestation, among others in richly

\footnotetext{
${ }^{65}$ Barber 1991, 26.

${ }^{66}$ Grömer 2016, 55.

${ }^{67}$ Słomska and Antosik 2017, 31-38.

${ }^{68}$ Costin 1991, 3 .

${ }^{69}$ Costin 1991, 4.

${ }^{70}$ Andersson Strand 2003, 47.

${ }^{71}$ Grömer 2016, 247.

${ }^{72}$ Grömer 2016, 249.
} 
equipped princely graves. Fabrics from this period (for example from the salt mine from Hallstatt or the princely grave at Hochdorf) definitely outweigh the quality of those from the earlier period. These are fabrics with complex weaves, some dyed with imported dyes. ${ }^{73}$ To create them, specialised craftsmen were needed. Social status and its visualisation were perhaps achieved through textiles and clothing. Thus, it is possible, at least for the circle of the Hallstatt Culture, that attached specialist production did exist. ${ }^{74}$

Regarding the settlement at Ruda, it seems that it was household production for own use. The collection of discovered spindle whorls indicates that spinning was a universal skill, and their diversity testifies to the production of yarn of various parameters, made both from flax and wool. The remains of the warp-weighted loom indicate that fabrics were also produced in the settlement. This conclusion is all the more justified because of the fact that the settlement, although quite extensive, was inhabited during several phases. Thus, at one time, several families could live within it and could produce necessary products on a regular basis.

Similar conclusions about household textile production can be drawn for other "open" settlements of the Lusatian Culture. Perhaps a higher level of organisation of production and specialisation (household industry) existed in fortified settlements dated to the Early Iron Age, for example those at Biskupin, Bnin, Komorowo or Smuszewo. These settlements were built during the period of profound social changes. Fortified settlements protected the population from outside danger. The Lusatian communities that built these settlements had to be well organised and managed because such an extensive project could last even several years.

Certainly, bronze and amber workshops in the settlements of the Lusatian Culture were at a higher level of specialisation and organisation of production. Was the textile industry organised at a similar level? It is difficult to answer this question. The Hallstatt period hillfort of Smolenice-Molpír ${ }^{75}$ is an example of a specialised textile production centre related to the Hallstatt Culture in Slovakia. Over 200 loom weights and 2100 spindles whorls were discovered there. Such a collection of these artefacts clearly indicates that textile production was in the hands of qualified specialists. ${ }^{76}$ In the settlement of the Lusatian Culture at Biskupin, several hundred fragments and only 14 intact loom weights and 41 spindle whorls were discovered. ${ }^{77}$ These objects, grouped in several or several dozen fragments, occurred throughout the entire settlement within houses and in cultural layers. In other settlements (for example at Bnin, Smuszewo, Komorowo) the number of loom weights and spindle whorls is lower - from several to several dozen fragments. According to Justyna

\footnotetext{
${ }^{73}$ Grömer 2016, 254.

${ }^{74}$ Grömer 2016, 254.

${ }^{75}$ Belanová-Štolcová 2012, 210.

${ }^{76}$ Grömer 2016, 285.

${ }^{77}$ Szafrański 1950, 132-160.
}

$\dot{Z}$ ychlinska, ${ }^{78}$ the hypothesis on the existence of at least two specialised textile centres in Greater Poland is not supported by sufficient evidence. Furthermore, although considerations on the level of organisation and specialisation of textile production in the Lusatian Culture are very interesting, the lack of specialised research in this field does not allow for such far-reaching conclusions.

Taking into account the imports such as fibulae, belt buckles, pincers, razors and swords from the Hallstatt Culture area flowing into the area of the Lusatian Culture, ${ }^{79}$ it should be considered whether the fabrics were also a subject to the influence of the Alpine zone. Textiles from Świbie and twills from Domasław could be mentioned as examples. ${ }^{80}$ Not only jewellery and weapons could be exchanged. Were Hallstatt glamorous fabrics of different weaves, patterns and colours ${ }^{81}$ objects of desire, similarly to bronze artefacts? Could new weaving techniques (like twills and tablet weaving) ${ }^{82}$ have migrated together with representatives of the Hallstatt cultural circle and reach the Lusatian community? And if so, are these interactions discernible in the archaeological material? The answers to these questions may be provided by the research currently being conducted by Słomska and Antosik, ${ }^{83}$ Grossmann, and the author of the article.

\section{Conclusion}

Rescue research at Ruda provided a huge collection of archaeological artefacts of great value, proving the knowledge and high level of many crafts among the communities living in this area in the Late Bronze Age and the Early Iron Age. Among other things, it also included advanced skills of textile manufacture. Spinning and weaving are confirmed by finds of spindle whorls, a fragment of a loom weight and Feature 1351F, interpreted as a remnant of a warp-weighted loom. The use of such raw materials as flax and wool is also confirmed by archaeozoological and botanical data.

From the point of view of the organisation of textile manufacture in the settlement in question, the most important is the fact that most artefacts were discovered within distinguished households. Together with accompanying storage pits, these households formed close single enclosures. The dispersion of spindle whorls within enclosures is significant.

Another interesting issue is the existence of a textile specialisation in relation to the "Lusatian" communities. Can homesteads, where clusters of loom weights or a greater number of spindle whorls were discovered, be referred to as specialised workshops? Is it possible to assume that in settlements or hillforts there were special buildings (uninhabited

\footnotetext{
${ }^{78}$ Żychlińska 2017, 39.

${ }^{79}$ Gedl 1992, 23, 27.

${ }^{80}$ Słomska and Antosik 2017, 36.

${ }^{81}$ Grömer et al. 2013.

${ }^{82}$ Grömer 2016, 135, 180.

${ }^{83}$ Słomska and Antosik 2017, 36.
} 
and intended for the whole community) whose only function was textile manufacture ${ }^{84}$ The level of certain specialisation has already been suggested by Szafrański. ${ }^{85}$ He says about the "weaving workshop" with regard to House 37 at Biskupin. However, according to the author, for now we cannot exclude or confirm these assumptions based on the current state of research. Verification of these hypotheses requires in-depth studies in the field of organisation and management of space in settlements of the Lusatian Culture.

\section{Bibliography}

Andersson Strand E. 2003. Textile Production in Scandinavia during the Viking Age. In: L. Bender-Jørgensen, J. Banck-Burgess, A. East-Reicher (eds.), Textilien aus Archäologie und Geschichte. Festschrift für Klaus Tidow. Neumünster, 47-62.

Andersson Strand E., Nosch M.-L. (eds.) 2015. Tools, Textiles and Context. Investigating Textile Production in the Aegean and Eastern Mediterranean Bronze Age. Ancient Textiles Series 21. Oxford, Philadelphia.

Barber E. J. W. 1991. Prehistoric Textiles. The Development of Cloth in the Neolithic and Bronze Ages with Special Reference to the Aegean. Princeton.

Becker C., Benecke N., Grabundžija A., Kühelmann Ch., Pollock S., Schier W., Schoch C., Schrakamp I., Schütt B., Schumacher M. 2016. The Textile Revolution. Research into the Origin and Spread of Wool Production between the Near East and Central Europe. In: G. Graßhoff, M. Meyer (eds.), “eTOPOI. Journal for Ancient Studies. Special Volume 6: Space and Knowledge. Topoi Research Group Articles”, 102-151. (http://journal.topoi.org/index.php/etopoi/article/view/253, accessed 11.06.2018).

Bednarczyk J. 2000. Życie codzienne w okresie rzymskim. In: M. Chłodnicki, L. Krzyżaniak (eds.), Gazociag pełen skarbów archeologicznych. Poznań, 73-98.

Belanová-Štolcová T. 2012. Slovak and Czech Republic. In: M. Gleba, U. Mannering (eds.), Textiles and Textile Production in Europe: From Prehistory to AD 400. Ancient Textiles Series 11. Oxford, Oakville, 306-333.

Bergfjord C., Mannering U., Frei K. M., Gleba M., Scharff A. B., Skals I., Heinemeier J., Nosch M.-L., Holst B. 2012. Nettle as a Distinct Bronze Age Textile Plant. "Nature Scientific Reports" 2 (664), 1-4.

Bienias D. 2006. Charakterystyka fizjograficzna. In: Opracowanie wyników ratowniczych badań archeologicznych przeprowadzonych na odcinku Al planowanej autostrady w woj. kujawsko-pomorskim (b. woj. toruńskie). Ruda, gm. Gru$d z i a d z$, stanowiska 3-6, t. 16a. Typescript in the archive of the Institute of Archaeology, Nicolaus Copernicus University. Toruń, 10-11.

Bogusławski J. 1967. Włókiennictwo - najstarszy przemyst świata. Warszawa.

Brown A. 2017. Nettles for Textiles. (www.nettlesfortextiles.org.uk, accessed 25.05.2018).

Chmielewski T. J. 2009. Po nitce do kłębka... O przędzalnictwie i tkactwie młodszej epoki kamienia w Europie Środkowej. Warszawa.

Chmielewski T. J., Gardyński L. 2009. Włókno - nić - wrzeciono. Z metodyki badań przesślików na przykładzie znalezisk ze stanowiska 1C w Gródku. In: H. Taras, A. Zakościelna (eds.), Hereditas praeteriti: Addimenta archaeologica et historica dedicate Ioanni Gurba Octogesimo Anno Nascendi. Lublin, 145-157.

Chudziak W. 2006a. Wprowadzenie. In: Opracowanie wyników ratowniczych badań archeologicznych przeprowadzonych na odcinku Al planowanej autostrady w woj. kujawsko-pomorskim (b. woj. toruńskie). Ruda, gm. Grudziadz, stanowiska 3-6, t. 16a. Typescript in the archive of the Institute of Archaeology, Nicolaus Copernicus University. Toruń, 6-8.

Chudziak W. 2006b. Wyniki prac terenowych. In: Opracowanie wyników ratowniczych badań archeologicznych przeprowadzonych na odcinku Al planowanej autostrady w woj. kujawsko-pomorskim (b. woj. toruńskie). Ruda, gm. Gru$d z i q d z$, stanowiska 3-6, t. 16a. Typescript in the archive of the Institute of Archaeology, Nicolaus Copernicus University. Toruń, 15-20.

Chudziakowa J. 1992. Grodzisko kultury tużyckiej w Gzinie (źródta archeologiczne). Toruń.

Costin C. L. 1991. Craft Specialization: Issues in Defining, Documenting, and Explaining the Organization of Production. "Archaeological Method and Theory" 3, 1-56.

Dąbrowski J. 2010. Uwagi o wiedzy medycznej ludności kultury łużyckiej. "Materiały i Sprawozdania Rzeszowskiego Ośrodka Archeologicznego" 31, 45-50.

Durczewski D. 1985. Gród ludności kultury tużyckiej w Smuszewie, woj. pilskie. Poznań.

Dzięgielewski K. 2011. Moczydła do lnu? Nowa hipoteza dotyczaca funkcji jam szczelinowych (Schlitzgruben) z epoki brązu i żelaza. In: K. Dzięgielewski, Ł. Oleszczak (eds.), Po drugiej stronie... Raporty przyjaciót-archeologów dla Wojtka Cholewy ,Jonesa”. Pękowice, 101-139.

\footnotetext{
${ }^{84}$ Żychlińska 2017, 41.

${ }^{85}$ Szafrański 1950, 154.
} 
Gackowski J. 2009. Osada obronna z początku epoki żelaza w Grodnie koło Chetmży w świetle dotychczasowych odkryć. In: M. Fudziński, H. Paner, S. Czopek (eds.), Nowe materiaty kultury tużyckiej i pomorskiej z Pomorza. Gdańsk, 25-36.

Gedl M. 1992. Wplywy halsztackie w Polsce. In: S. Czopek (ed.), Ziemie polskie we wczesnej epoce żelaza i ich powiazania z innymi terenami. Rzeszów, 23-30.

Grömer K. 2005. Efficiency and Technique - Experiments with Original Spindle Whorls. In: P. Bichler, K. Grömer, R. Hofmann-de Keijzer, A. Kern, H. Reschreiter (eds.), "Hallstatt Textiles". Technical Analysis, Scientific Investigation and Experiments on Iron Age Textiles. British Archaeological Reports International Series 1351. Oxford, 107-116.

Grömer K. 2016. The Art of Prehistoric Textile Making. The Development of Craft Traditions and Clothing in Central Europe. Veröffentlichungen der Prähistorischen Abteilung 5. Vienna.

Grömer K., Kern A., Reschreiter H., Rösel-Mautendorfer H. 2013. Textiles from Hallstatt. Weaving Culture in Bronze and Iron Age Salt Mines. Textilien aus Hallstatt. Gewebte Kultur aus dem bronze- und eisenzeitlichen Salzbergwerk. Archaeolingua 29. Budapest.

Harding A. 2000. European Societies in the Bronze Age. Cambridge.

Harding A., Ostoja-Zagórski J., Palmer C., Rackham J. 2004. Sobiejuchy: a Fortified Site of the Early Iron Age in Poland. Warszawa.

Horst F. 1985. Zedau: eine jungbronze- und eisenzeitliche Siedlung in der Altmark. Berlin.

Kania K. 2013. The Spinning Experiment: Influences on Yarn in Spinning with a Hand-Spindle. In: H. Hopkins (ed.), Ancient Textiles, Modern Science: Re-creating Techniques through Experiment: Proceedings of the First and Second European Textile Forum 2009 and 2010. Oxford, Oakville, 11-29.

Kasprzyk K., Polcyn M. 2006. Wyniki analizy paleobotanicznej. In: Opracowanie wyników ratowniczych badań archeologicznych przeprowadzonych na odcinku A-1 planowanej autostrady w woj. kujawsko-pomorskim (b. woj. toruńskie), Ruda, gm. Grudziadz, stanowisko 3-6, t. 16a. Typescript in the archive of the Institute of Archaeology, Nicolaus Copernicus University. Toruń, 47-48.

Kimbrough Ch. K. 2006. Spindle Whorls, Ethnoarchaeology, and the Study of Textile Production in Third Millennium BCE Northern Mesopotamia: A Methodological Approach. Unpublished PhD thesis. University of New York.

Kondracki J. 2000. Geografia regionalna Polski. Warszawa.

Kostrzewski J., Chmielewski W., Jażdżewski K. 1965. Pradzieje Polski. Wrocław, Warszawa, Kraków.

Kowaljuk N. 2006. Wyniki datowania radiowęglowego. In: Opracowanie wyników ratowniczych badań archeologicznych przeprowadzonych na odcinku A1 planowanej autostrady w woj. kujawsko-pomorskim (b. woj. toruńskie). Ruda, gm. Grudziądz, stanowiska 3-6, t. 16a. Typescript in the archive of the Institute of Archaeology, Nicolaus Copernicus University. Toruń, 23-26.

Makowiecki D. 2006. Wyniki analizy archeozoologicznej. In: Opracowanie wyników ratowniczych badań archeologicznych przeprowadzonych na odcinku Al planowanej autostrady w woj. kujawsko-pomorskim (b. woj. toruńskie). Ruda, gm. Grudziadz, stanowiska 3-6, t. 16a. Typescript in the archive of the Institute of Archaeology, Nicolaus Copernicus University. Toruń, 39-41.

Martin E., Murphy P. 1988. West Row Fen, Suffolk: A Bronze Age Fen-Edge Settlement Site. “Antiquity” 62, 353-358.

Mårtensson L., Andersson E., Nosch M.-L., Batzer A. 2005-2006. Technical Report. Experimental Archaeology Part 1, Tools and Textiles - Texts and Contexts Research Programme. The Danish National Research Foundation's Centre for Textile Research (CTR), Copenhagen, (https://ctr.hum.ku.dk/research-programmes-and-projects/previous-programmes-and-projects/tools/technical_report_1_experimental_archaeology.pdf, accessed 19.04.2018).

Mårtensson L. 2007. Investigating the Function of Mediterranean Bronze Age Textile Tools Using Wool and Flax Fibres. Experimentelle Archäologie in Europa. Bilanz 2007. Heft 6, 97-106.

Montelius O. 1900. Die Chronologie der ältesten Bronzezeit in Norddeutschland und Skandinavien. Stockholm.

Pawlak E., Pawlak P. 2008. Pradziejowe i wczesnośredniowieczne pozostałości osadnictwa na stanowisku 24 w Brońsku, gm. Śmigiel. In: B. Gruszka (ed.), Ad Oderam fluvium. Księga dedykowana pamięci Edwarda Dąbrowskiego. Zielona Góra, Świdnica, 211-240.

Poczobutt S. 1960. Ogólna technologia włókien lnianych. In: S. Poczobutt (ed.), Technologia lnu. Warszawa.

Reinecke P. 1924. Zur chronologischen Gliederung der süddeutschen Bronzezeit. "Germania” 8, 43-44.

Rembisz A. 2006. Kultura tużycka. In: Opracowanie wyników ratowniczych badań archeologicznych przeprowadzonych na odcinku Al planowanej autostrady w woj. kujawsko-pomorskim (b. woj. toruńskie). Ruda, gm. Grudziadz, stanowiska 3-6, t. 16b. Typescript in the archive of the Institute of Archaeology, Nicolaus Copernicus University. Toruń, 162-405.

Rembisz-Lubiejewska A. 2015. Ruda (stan. 3-6), gm. Grudziądz. Osada z młodszej epoki brązu i wczesnej epoki żelaza na tle osadnictwa Kotliny Grudziadzkiej. Typescript in the archive of the Institute of Archaeology, Nicolaus Copernicus University. Toruń.

Siciński W. 2008. Zespół urządzeń do wstępnej obróbki lnu z osady kultury przeworskiej z młodszego okresu przedrzymskiego w Kolonii Orenice na stan. 3, pow. Łęczyca. In: A. Buko, W. Duczko (eds.), Przez granice czasu. Księga poświęcona profesorowi Jerzemu Gąsowskiemu. Pułtusk, 79-87. 
Sielicka K. 2014. Ceramika nienaczyniowa z osady kultury tużyckiej w Grzybianach, stan. 3. In: T. Stolarczyk, J. Baron (eds.), Osada kultury pól popielnicowych w Grzybianach koło Legnicy. Legnica, Wrocław, 301-312.

Słomska J., Antosik Ł. 2017. Textile Products from Świbie. In: M. Bravermanová, H. Březinová, J. Malcolm-Davies (eds.), Archaeological Textiles - Links Between Past and Present. North European Symposium for Archaeological Textiles XIII. Liberec, Praha, 31-38.

Stahlhofen H. 1978. Eine spätbronzezeitliche Webstuhlgrube in Wallwitz, Kr. Burg. "Ausgrabungen und Funde" 23, $179-183$.

Szafrański W. 1950. Ciężarki tkackie i przęśliki z grodu kultury łużyckiej w Biskupinie. In: J. Kostrzewski J. (ed.), III Sprawozdanie z prac wykopaliskowych $w$ grodzie kultury tużyckiej $w$ Biskupinie $w$ powiecie żnińskim, za lata 1938-1939 i 1946-1948. Poznań, 132-160.

Troldtoft Andresen S., Karg S. 2011. Retting Pits for Textile Fibre Plants at Danish Prehistoric Sites Dated between 800 B.C. and A.D. 1050. "Vegetation History and Archaeobotany" 20 (517). (https://doi.org/10.1007/s00334-011-0324-0, accessed 22.01.2018).

Żychlińska J. 2016. Kilka uwag o warsztatach tkackich ludności kultury tużyckiej. "Materiały Zachodniopomorskie. Nowa Seria" 12, 133-147.

Żychlińska J. 2017. Kobieta kultury łużyckiej w przestrzeni społecznej. Bydgoszcz.

Żychliński D. 2007. Ratownicze badania wykopaliskowe na stan. 21 w Daniszewie, pow. Koło, woj. wielkopolskie (nr autostradowy A2 - 411) - komunikat z badań. "Wielkopolskie Sprawozdania Archeologiczne" 8, 153-162.

\section{Streszczenie}

\section{Organizacja produkcji włókienniczej w osadnictwie kultury łużyckiej w Rudzie, powiat grudziądzki}

Przedmiotem niniejszego artykułu jest organizacja produkcji włókienniczej w osadzie ludności kultury łużyckiej w miejscowości Ruda, pow. grudziądzki, województwo kujawsko-pomorskie. Na stanowisku tym odkryto 63 przęśliki, dwa ciężarki tkackie oraz obiekt archeologiczny $(1351 \mathrm{~F})$, interpretowany jako pozostałość po ciężarkowym warsztacie tkackim. Zabytki te wywołały dyskusję nad organizacją produkcji włókienniczej w osadzie. Pozostałości po staciwach krosna w obiekcie 1351F znajdują analogie w strukturach archeologicznych w Wallwitz w Saskonii. Najistotniejszym z punktu widzenia organizacji produkcji włókienniczej w omawianej osadzie, jest fakt, iż zdecydowaną większość zabytków odkryto w obrębie wyróżnionych domostw, tworzących wraz z towarzyszącymi jamami gospodarczymi zwarte, pojedyncze zagrody. Rozmieszczenie przęślików w obrębie poszczególnych enklaw wydaje się być znaczące. 
